University of Nebraska - Lincoln

DigitalCommons@University of Nebraska - Lincoln

Responses of Dabbling Ducks to Wetland Conditions in the Prairie Pothole Region

Jane Austin

U.S. Geological Survey, jaustin@usgs.gov

Follow this and additional works at: https://digitalcommons.unl.edu/usgsnpwrc

Part of the Other International and Area Studies Commons

Austin, Jane, "Responses of Dabbling Ducks to Wetland Conditions in the Prairie Pothole Region" (2002). USGS Northern Prairie Wildlife Research Center. 5.

https://digitalcommons.unl.edu/usgsnpwrc/5

This Article is brought to you for free and open access by the US Geological Survey at DigitalCommons@University of Nebraska - Lincoln. It has been accepted for inclusion in USGS Northern Prairie Wildlife Research Center by an authorized administrator of DigitalCommons@University of Nebraska - Lincoln. 


\title{
Responses of Dabbling Ducks to Wetland Conditions in the Prairie Pothole Region
}

\author{
JANE E. AUSTIN \\ U.S. Geological Survey, Northern Prairie Wildlife Research Center, 8711 37th Street SE \\ Jamestown, ND 58401, USA \\ Internet: jane_austin@usgs.gov
}

\begin{abstract}
The relationships between wetland water conditions and breeding numbers of Mallard (Anas platyrhynchos), Northern Pintail (A. acuta), Blue-winged Teal (A. discors), and Northern Shoveler (A. clypeata) during May of 1992-1995, were examined on twelve study areas in the eastern Prairie Pothole Region. Data were collected on water levels (by wetland class [temporary, seasonal, semipermanent]), pond density (density of wet basins), and numbers of indicated pairs for each species from weekly roadside transect surveys. Comparison of models relating duck numbers to wetlands using Akaike's Information Criterion indicated that measures of water condition generally were of similar value for explaining duck numbers. The model containing effects of semipermanent wetland water levels was among the best in explaining duck numbers for all species. Inclusion of temporary and seasonal wetland water levels in models for Mallard and Northern Pintail was not strongly supported by the data. Variation in duck numbers was much higher among areas than among years. Water conditions accounted for nearly all among-year variation for individual sites, but a large proportion of residual variation remained unexplained. Water condition measures (excluding spatial and temporal factors) explained 9-49\% of variation in duck numbers, leaving $51-91 \%$ unexplained. Comparisons of these results to those of studies conducted at local or regional scale indicated that the relationship between duck numbers and pond numbers varied with scale, and suggested that other arearelated factors should be considered at smaller landscape scales. Received 20 June 2002, accepted 10 August 2002.

Key words.-Anas acuta, Anas clypeata, Anas discors, Anas platyrhynchos, Blue-winged Teal, Mallard, Northern Pintail, Northern Shoveler, Prairie Pothole Region, scale, breeding waterfowl population, wetlands.
\end{abstract}

Waterbirds 25(4): 465-473, 2002

The positive relation between breeding duck numbers and pond densities (number of wet basins) has long been recognized, particularly in the Prairie Pothole Region (Evans and Black 1956; Crissey 1969; Dzubin 1969b; Johnson and Grier 1988; Batt et al. 1989). Among North American waterfowl, Mallard (Anas platyrhynchos), Northern Pintail (A. acuta), Blue-winged Teal (A. discors), and Northern Shoveler (A. clypeata) historically have shown the strongest responses to changes in both local and regional pond densities (Johnson and Grier 1988). The strongest relationships to pond densities have been demonstrated at a large regional scale (Johnson and Grier 1988; Batt et al. 1989), using strata of the annual Waterfowl Breeding Population and Habitat Survey (WBPHS) (U.S. Fish and Wildlife Service and Canadian Wildlife Service 1987). Results of studies conducted at smaller scales (individual study areas) have been variable (Drewien and Springer 1969; Leitch and Kaminski 1985; Johnson 1996).

Previous studies (cited above) used pond densities as the measure of regional wetland habitat quantity and quality, but other stud- ies documented relations between duck numbers and total water area, which is a function of pond density (density of wet basins), wetland size, and water levels within wetland basins (Stewart and Kantrud 1973; Cowardin et al. 1995; Cowardin et al. 1998). Cowardin et al. (1998) found that total water area explained more variation in duck numbers than did number of ponds for Mallard, Gadwall (A. strepera), Blue-winged Teal, and Northern Pintail, but not Northern Shoveler. When area of flooded wetland is unknown, water levels may serve as an alternate measure of wetland water conditions. Water levels may provide breeding ducks a proximate cue to local environmental conditions independent of pond density. For example, ducks may interpret shallow water depths and exposed mud flats in May as evidence of poor or declining habitat quality and move elsewhere to breed. In addition, as a measure of annual water conditions, water levels are much less dependent on land form (e.g., topography, soils), which can differ widely across the region (e.g., Kantrud et al. 1989), than are pond densities. 
To design and apply effective habitat management programs, we need a better understanding of habitat factors that attract ducks to an area and the appropriate scale at which those factors operate. The objective of this study was to determine the nature of variation (spatial, temporal, and relative to water conditions) in numbers of Mallard, Northern Pintail, Blue-winged Teal, and Northern Shoveler on twelve intermediatesized $\left(280 \mathrm{~km}^{2}\right)$ study areas across the eastern portion of the Prairie Pothole Region (Fig. 1). Several measures of water conditions were examined to determine which measures provided the best predictor of duck numbers and compare data collected at an intermediate landscape scale to results from studies that were conducted at local or large regional scales.

\section{STUDY AREAS}

Twelve study areas were selected that had high numbers of Northern Pintail during 1971-1990 (WBPHS data; U.S. Fish and Wildlife Service unpubl. data) because the species originally was a focus of the study, and to provide a distribution of areas from southeast to northwest, reflecting the movement of ducks into breeding areas of the Central Flyway (Bellrose 1980; Johnson and Grier 1988) (Fig. 1). Each study area consisted of three adjacent east-west townships $\left(280 \mathrm{~km}^{2}\right.$ total $)$, centered on an air:ground segment of the WBPHS; area names follow those used for the air:ground transects and usu-

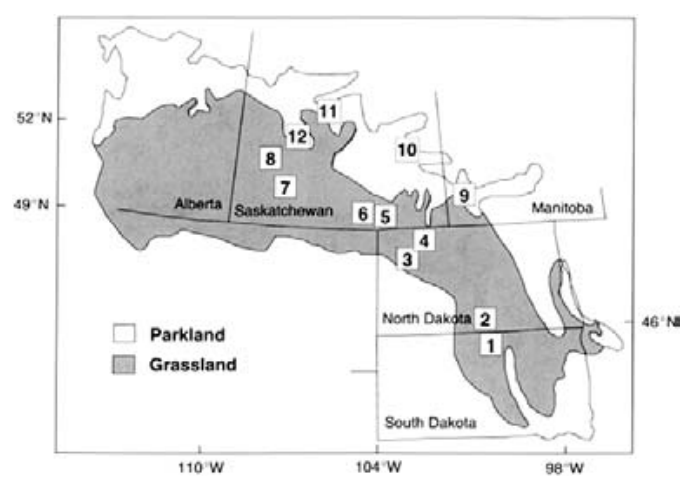

Figure 1. Map of the Prairie Pothole Region showing the locations of twelve study areas where weekly waterfowl surveys were conducted during May, 1992-1995. Study area 1 = Hosmer, South Dakota; 2 = Streeter, North Dakota; 3 = Plaza, North Dakota; 4 = Kenmare, North Dakota; 5 = Goodwater, Saskatchewan; 6 = Ceylon, Saskatchewan; 7 = Shamrock, Saskatchewan; 8 = Tichfield, Saskatchewan; 9 = Moore Park, Manitoba; 10 = Buchanan, Saskatchewan; 11 = Kinistino, Saskatchewan; and 12 = Hanley, Saskatchewan ally refer to the nearest community. Few access roads were available to establish a transect on the air:ground segment near the Shamrock, Saskatchewan, site so the three townships immediately to the south were selected as a study area. All study areas fell within WBPHS survey strata considered as the core breeding range (i.e., top $50 \%$ of average species density) for all four species (Johnson and Grier 1988).

Four study areas (Moore Park, Manitoba; and Hanley, Kinistino, and Buchanan, Saskatchewan) were located in prairie parkland habitat (Kiel et al. 1972); the remaining areas were in prairie grassland habitat. Densities of wetland basins, as measured within roadside transects established on each study area (see below), averaged 166.4 wetlands $/ \mathrm{km}^{2}$ (Hosmer: 158.7; Streeter: 158.7; Plaza: 255.7; Kenmare: 241.2; Goodwater: 156.6; Ceylon: 114.6; Shamrock: 112.3; Tichfield: 152.5; Moore Park: 204.5; Hanley: 180.1; Kinistino: 100.3; Buchanan: 165.6 wetlands $/ \mathrm{km}^{2}$ ). Temporary and seasonal wetlands combined accounted for $>75 \%$ of wetland basins in all areas except Moore Park, which contained a large proportion $(45 \%)$ of semipermanent wetlands (Fig. 2). More detailed descriptions of these areas are given in Greenwood et al. (1995).

\section{METHODS}

On each study area, a fixed-width transect $80.5 \mathrm{~km}$ (50 mi) long by $0.40 \mathrm{~km}(0.25 \mathrm{mi})$ wide, centered on road rights-of-way was established. Transects were designed to distribute sampling on roads through as much of the 3-township block as possible. Wetlands in United States study areas were identified from National Wetlands Inventory maps (NWI); wetlands in Canadian study areas were identified from township photo mosaics and by field visits to sites. Wetlands were mapped, numbered, and classified to wetland class (temporary, seasonal, semipermanent, or other; Stewart and Kantrud 1971) based on deepest water regime of NWI maps (United States areas) and ground-truthing (Canadian areas). Temporary roadside ditches were excluded from

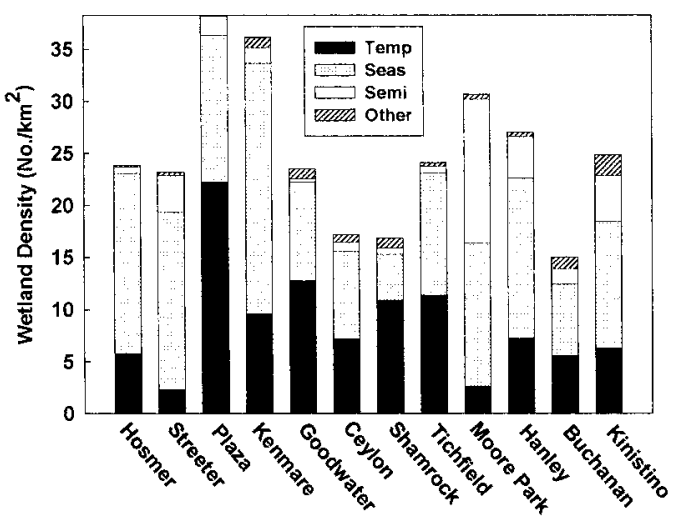

Figure 2. Density of wetland basins, by wetland class, in 80-5-km roadside transects on twelve study areas in the Dakotas, Manitoba, and Saskatchewan during 19921995. TEMP = temporary wetlands, SEAS = seasonal wetlands, SEMI = semipermanent wetlands, and OTHER = permanent and other wetland classes, and unclassified wetlands. 
consideration of wetland densities because these wetlands could not be consistently and accurately identified on the Canadian study areas; otherwise, all wetlands within road rights-of-way were included. Riverine or other wetlands were not considered here because of their rare occurrence.

Field personnel conducted duck surveys on each study area during each week in May, 1992-1995. Each year, data for each area were collected by one observer, who surveyed as much of the transect as possible during a 7-h daily survey period ( $06.00 \mathrm{~h}-13.00 \mathrm{~h}$ ). Each survey included $\geq 32 \mathrm{~km}$ and averaged $55.3 \pm 11.9 \mathrm{~km}$; the length of transect and proportion of wetland basins included in each weekly survey depended on road and weather conditions, visibility of wetlands from the road, and wetland and waterfowl densities. During each survey, personnel recorded numbers and social groups of Mallard, Northern Pintail, Blue-winged Teal, and Northern Shoveler within the transect (Dzubin 1969a). For each wetland observed, field personnel recorded an ocular estimate of the percentage of the wetland basin holding water as $0,5,25,50,75,100$, or $\geq 125 \%$ full (i.e., water level), relative to the wet meadow and shallow marsh zones (Stewart and Kantrud 1971). We also used NWI maps and photomosaics, which were from years with average water conditions, to help estimate water levels relative to average water conditions.

\section{Data Analysis}

From social group data recorded weekly, the numbers of indicated breeding pairs (IP) for each species were calculated following methods of Dzubin (1969a). To adjust IP for observer effort, IP was divided by the product of the number of kilometers surveyed and the proportion of basins surveyed within that surveyed length (i.e., number of wetlands observed/number of wetlands available in that transect portion). This adjusted number (corrected IP, or CIP), served as the population index.

To similarly adjust the measure of wetlands containing water per $\mathrm{km}$ for survey length and observer effort, the product of the proportion of sampled basins containing water and total number of basins available was divided by the number of kilometers surveyed. For each week and wetland class, two measures of water conditions were determined: (i) density of wetland basins containing $\geq 5 \%$ areal water (hereafter referred to as pond density), and (ii) mean water level.

Analyses of these data needed to take into consideration the possibility that observations on the same study area may have been correlated, and observations taken during the same year also may have been correlated. Therefore the error structure was considered to be crossed, and consisted of three components: $y_{i}$, the random effect of year; $a_{j}$, the random effect of study area; and $\varepsilon_{i j}$, the residual error associated with each study area and year. The model for the data was

$$
d_{i}=\mu+\beta w_{i j}+\left(y_{i}+a_{j}+\varepsilon_{i j}\right)
$$

where $d_{i}=$ index of duck numbers (continuous response variable), $\beta$ = regression coefficient reflecting the effect of water conditions on duck numbers, and $w_{i j}=$ water condition index (continuous covariate). The model was fit using a mixed linear model (SAS PROC MIXED; Littell et al. 1996). Akaike's Information Criterion for small samples $\left(\mathrm{AIC}_{\mathrm{c}}\right.$ ) was used to rank models (Burnham and
Anderson 1998). The model with the lowest $\mathrm{AIC}_{\mathrm{c}}$ was considered the best approximating model for the data, and other models with differences in $\mathrm{AIC}_{\mathrm{c}}\left(\Delta \mathrm{AIC}_{\mathrm{c}}=0\right)$ of $<3$ may represent potential best models (Burnham and Anderson 1998). The median value of CIP from the four weekly surveys was used as the population index for each species. Principal component analysis (PCA) was used to generate a composite measure of water condition that combined the mean water level for each wetland class (temporary, seasonal, and semipermanent). Simple linear regression was used to determine the proportion of variation of CIP explained by the various water measures.

\section{RESULTS}

\section{Wetland Conditions During the Study}

Water levels in temporary, seasonal, and semipermanent wetlands (Fig. 3) varied markedly among years and study areas. In the U.S. Prairie Pothole Region, the first two years of the study came at the end of an extended and severe drought. Water levels were particularly low in the United States areas in 1992 and 1993. Heavy rains in the United States areas starting mid-summer 1993, and continuing through 1995, resulted in increasingly wet conditions in those areas. Many wetlands in Hosmer, Streeter, and Kenmare were overflowing (>100\% full) by 1995 . In the Canadian grassland areas (Goodwater, Ceylon, Shamrock, and Tichfield), mean water levels in seasonal and semipermanent wetlands generally were lowest in 1993 and 1995. Tichfield maintained relatively constant water conditions over the four years, but mean water levels of seasonal wetlands never exceeded $30 \%$. Patterns of water conditions in the four parkland areas were mixed. Moore Park was the wettest of all twelve study areas in 1992. The easternmost parkland areas (Moore Park, Kinistino, and Buchanan) were driest in 1993 and 1994 and experienced early spring flooding in 1995. Water levels were most consistent among years in Hanley, but mean water levels in May never exceeded $50 \%$. Mean water levels for temporary wetlands in Canada were $\leq 33 \%$ for all areas-years except Hanley in 1995.

\section{Annual Variation in Duck Population Indices}

Indices of duck numbers averaged 0-3 CIP in most study areas and years. In 1993, indices for all species were particularly low 


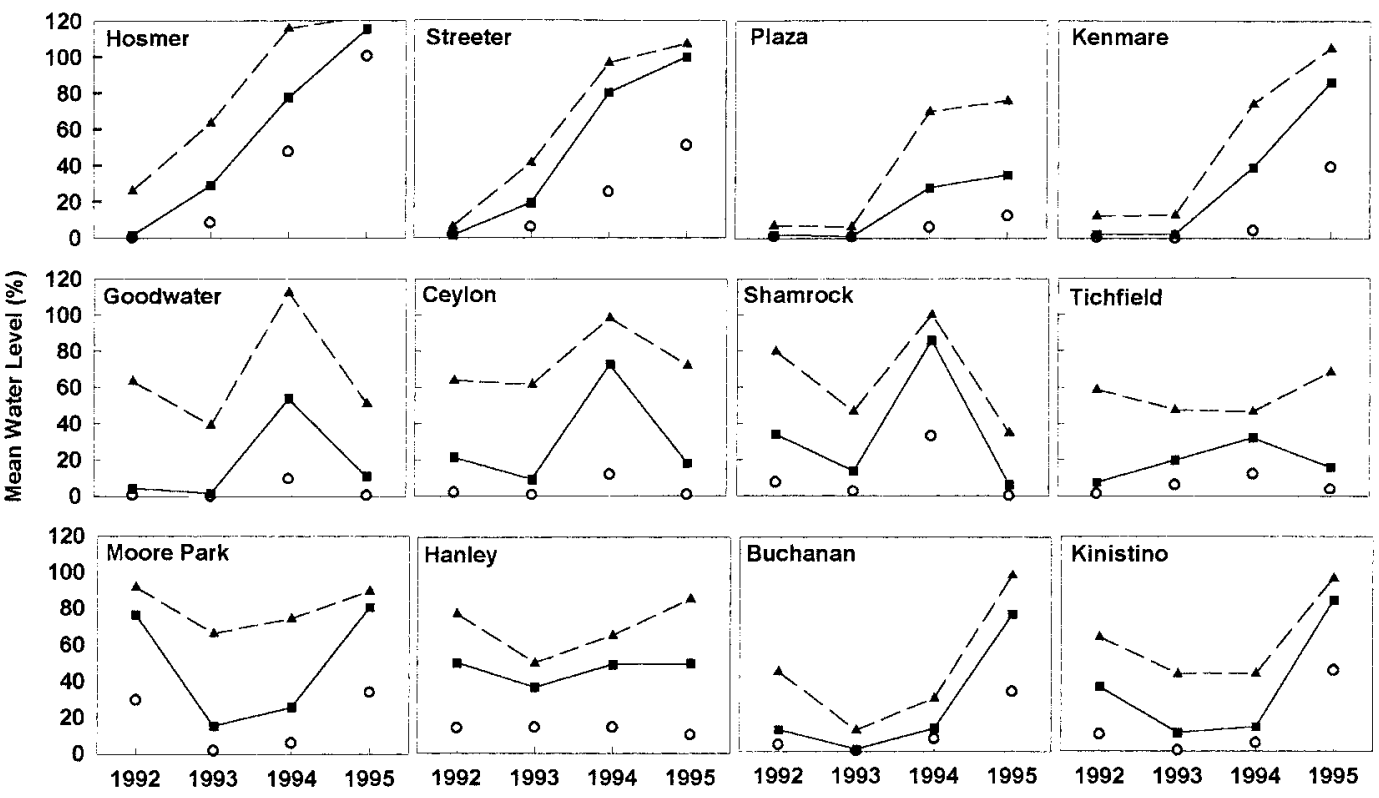

Figure 3. Mean water levels of temporary (open circle), seasonal (square), and semipermanent (triangle) wetlands in twelve study areas in the Dakotas, Manitoba, and Saskatchewan during May, 1992-1995.

$(\leq 1.5 \mathrm{CIP})$ in the four Dakota study areas and Goodwater. Indices were most variable in three areas. In Hosmer and Streeter, indices of Blue-winged Teal increased substantially during 1994 and 1995. In Hanley, indices of Mallard were markedly higher in 1992 and 1995 than in 1993 or 1994 , and indices of Blue-winged teal were highest in 1992 (Fig. 4).

Response of Duck Population Indices to Water Conditions

The first principle component (PC1) consisted of strong contributions from all three variables (loadings: temporary wetland water levels, 0.360; seasonal wetland water levels, 0.677; semipermanent wetland water levels, 0.643). While all three variables were strongly associated with PC1, mean water levels in seasonal wetlands were most strongly correlated with it $(r=0.979)$, followed by that for semipermanent wetlands $(r=0.947)$; mean water levels in temporary wetlands had the weakest correlation $(r=0.867)$. Therefore, mean water level in seasonal wetlands was chosen to represent water levels in subsequent analyses because it was the simplest and most direct measure.
In general, duck indices were related to measures of wetland condition (Table 1). Consistently low $\triangle \mathrm{AIC}$ values of models containing effects of semipermanent wetland water levels indicated that this parameter was among the best in explaining duck numbers for all species. By species, the best-fitting models contained effects of temporary water levels and PC1 for Blue-winged Teal, semipermanent water levels for Mallard and Northern Pintail, and PC1 for Northern Shoveler. For Blue-winged Teal, the analysis indicated relatively small differences $\left(\Delta \mathrm{AIC}_{\mathrm{c}}<4.1\right.$; Table 1) among the five models containing effects of water conditions, suggesting the models were of similar value for explaining Blue-winged Teal indices. Similarly, models containing four of the five measures of water conditions (excluding temporary water levels) were essentially equivalent $\left(\Delta \mathrm{AIC}_{\mathrm{c}}<6.4\right.$; Table 1) for explaining Northern Shoveler indices. For Northern Pintail, the high $\triangle \mathrm{AIC}_{\mathrm{c}}$ for models containing effects of temporary and seasonal water levels and effects of pond density indicated inclusion of these measures was poorly supported by the data.

Examination of variance components (Table 2) indicated variation in duck indices 
Table 1. Model selection by lowest $\mathrm{AIC}_{\mathrm{c}}$ value for base model (area and year) and for five measures of water conditions. A zero for each dependent variable indicates lowest $\mathrm{AIC}_{\mathrm{c}}$ among all models for that species, and all other values are differences from the lowest $\mathrm{AIC}_{\mathrm{c}}$. $\mathrm{PC} 1$, the first principal component from principal component analyses, was a combination of five measures of wetland condition: mean water level for each wetland class (temporary, seasonal, and semipermanent), a linear combination of these three measures, and pond density.

\begin{tabular}{|c|c|c|c|c|c|c|}
\hline \multirow[b]{3}{*}{ Species } & \multicolumn{6}{|c|}{ Models } \\
\hline & \multirow[b]{2}{*}{$\begin{array}{l}\text { Base model } \\
\qquad \Delta \mathrm{AIC}_{\mathrm{c}}\end{array}$} & \multicolumn{3}{|c|}{ Water levels } & \multirow[b]{2}{*}{$\begin{array}{l}\text { Pond } \\
\text { density } \\
\Delta \mathrm{AIC}_{\mathrm{c}}\end{array}$} & \multirow[b]{2}{*}{$\begin{array}{c}\text { PC1 } \\
\Delta \mathrm{AIC}_{\mathrm{c}}\end{array}$} \\
\hline & & $\begin{array}{c}\text { Temporary } \\
\text { wetlands } \\
\Delta \mathrm{AIC}_{\mathrm{c}}\end{array}$ & $\begin{array}{l}\text { Seasonal } \\
\text { wetlands } \\
\Delta \mathrm{AIC}_{\mathrm{c}}\end{array}$ & $\begin{array}{c}\text { Semipermanent } \\
\text { wetlands } \\
\Delta \mathrm{AIC}_{\mathrm{c}}\end{array}$ & & \\
\hline Blue-winged Teal & 22.9 & 0.2 & 1.9 & 4.1 & 1.1 & 0 \\
\hline Mallard & 11.0 & 15.0 & 10.6 & 0 & 4.9 & 6.3 \\
\hline Northern Pintail & 18.2 & 20.5 & 10.0 & 0 & 11.7 & 5.5 \\
\hline Northern Shoveler & 30.9 & 14.4 & 3.8 & 2.3 & 6.4 & 0 \\
\hline
\end{tabular}

was much higher among areas than among years. Unexplained variation from the base model was large for all species and in particular for the Blue-winged Teal. Annual variation was almost completely captured by variation in each measure of water condition, and results were generally similar among species. However, a relatively large amount of residual

Table 2. Variance components for base models (area and year) and for models including each of five measures of water conditions. PC1, the first principal component from principal component analyses, was a combination of five measures of wetland condition: mean water level for each wetland class (temporary, seasonal, and semipermanent), a linear combination of these three measures, and pond density.

\begin{tabular}{|c|c|c|c|c|}
\hline \multirow[b]{2}{*}{ Model } & \multirow[b]{2}{*}{ Species } & \multicolumn{3}{|c|}{ Variance component } \\
\hline & & Area & Year & Residual \\
\hline \multirow[t]{4}{*}{ Base } & Blue-winged Teal & 2.2891 & 0.2693 & 4.2701 \\
\hline & Mallard & 0.7031 & 0.1376 & 0.6779 \\
\hline & Northern Pintail & 0.1515 & 0.0646 & 0.2502 \\
\hline & Northern Shoveler & 0.4116 & 0.1072 & 0.6394 \\
\hline \multirow[t]{4}{*}{ Temporary wetland water levels } & Blue-winged Teal & 0.9831 & 0 & 2.6858 \\
\hline & Mallard & 0.6649 & 0.0221 & 0.6820 \\
\hline & Northern Pintail & 0.1244 & 0.0166 & 0.2391 \\
\hline & Northern Shoveler & 0.3491 & 0 & 0.4108 \\
\hline \multirow[t]{4}{*}{ Seasonal wetland water levels } & Blue-winged Teal & 1.3630 & 0 & 2.6415 \\
\hline & Mallard & 0.5389 & 0.0200 & 0.6184 \\
\hline & Northern Pintail & 0.1265 & 0 & 0.1957 \\
\hline & Northern Shoveler & 0.2874 & 0 & 0.3147 \\
\hline \multirow{4}{*}{$\begin{array}{l}\text { Semipermanent wetland } \\
\text { water conditions }\end{array}$} & Blue-winged Teal & 2.0826 & 0 & 2.4980 \\
\hline & Mallard & 0.5549 & 0.0364 & 0.4512 \\
\hline & Northern Pintail & 0.1406 & 0 & 0.1467 \\
\hline & Northern Shoveler & 0.3784 & 0 & 0.2826 \\
\hline \multirow[t]{4}{*}{ Pond density } & Blue-winged Teal & 2.3890 & 0 & 2.4789 \\
\hline & Mallard & 0.4291 & 0.0332 & 0.6130 \\
\hline & Northern Pintail & 0.2260 & 0 & 0.1999 \\
\hline & Northern Shoveler & 0.4541 & 0 & 0.3364 \\
\hline \multirow[t]{4}{*}{ PC1 } & Blue-winged Teal & 1.5015 & 0 & 2.4194 \\
\hline & Mallard & 0.5470 & 0.0176 & 0.5539 \\
\hline & Northern Pintail & 0.1263 & 0 & 0.1753 \\
\hline & Northern Shoveler & 0.3176 & 0 & 0.2791 \\
\hline
\end{tabular}


variation still remained after considering variation due to water conditions.

Simple linear regression of duck indices to water condition measures (exclusive of spatial and temporal factors) indicated 9-49\% of variation in duck numbers was explained by water conditions (Table 3), leaving 51-91\% unexplained. The poorest regressions related temporary wetland water levels to Mallard and Northern Pintail indices, and pond density to Northern Pintail indices.

\section{DISCUSSION}

Results from this study confirm earlier studies that demonstrated positive relationships between water conditions and duck numbers in the Prairie Pothole Region. That water conditions captured nearly all amongyear variation in this study demonstrates that wetland habitat conditions were key to yearto-year variation in duck numbers. The absence of large differences among most models containing various measures of water condition suggests that the five measures examined here were strongly associated with wetland habitat conditions. For Mallard and Northern Pintail, however, inclusion of temporary and seasonal water levels in models was not strongly supported by the data. The results for the Northern Pintail were somewhat surprising, given the strong perceived association of this species with shallow flooded wetlands (Austin and Miller 1995). The poor fit is probably affected by the relatively low variation in mean water levels for temporary wetlands.
Overall, mean water level in semipermanent wetlands was the most consistent predictor of duck numbers on study sites. This may be due to a number of factors related to our ability to discriminate and measure differences. First, semipermanent wetlands usually contained water throughout the sampling period, whereas temporary wetlands (and, during very dry years, seasonal wetlands) often were dry by mid-May, thus limiting variation. Variation in pond density may be similarly limited in drier years on areas where temporary and seasonal wetlands comprise a large proportion of wetland basins. Second, I suspect observers were probably better able to discriminate among conditions in semipermanent wetlands because they could relate it to more distinctive marsh zones (Stewart and Kantrud 1971).

Consideration of only water conditions left a large proportion of variation in duck numbers among sites unexplained, regardless of the measure used. This and the strong area component of variance in all models indicate area-related factors also may be important in explaining duck numbers. Predictive models for duck numbers in the Prairie Pothole Region would likely be stronger if they included other measures that are related to area. Likely factors to include are upland habitat conditions (e.g., proportion in grassland or cropland [Greenwood et al. 1995]), composition of wetland habitat (proportion of basins that are temporary, seasonal, or semipermanent wetlands), some measure of the condition of those wetlands (e.g., extent to which wetland margins or

Table 3. Simple linear regression $\left(r^{2}\right)$ of water conditions relative to numbers for four species of ducks on twelve study areas and four years. PC1, the first principal component from principal component analyses, was a combination of five measures of wetland condition: mean water level for each wetland class (temporary, seasonal, and semipermanent wetlands), a linear combination of these three measures, and pond density.

\begin{tabular}{|c|c|c|c|c|c|}
\hline \multirow[b]{2}{*}{ Species } & \multicolumn{3}{|c|}{ Water level } & \multirow[b]{2}{*}{$\begin{array}{c}\text { Pond density } \\
r^{2}\end{array}$} & \multirow[b]{2}{*}{$\begin{array}{c}\text { PC1 } \\
r^{2}\end{array}$} \\
\hline & $\begin{array}{c}\text { Temporary } \\
\text { wetlands } \\
r^{2}\end{array}$ & $\begin{array}{c}\text { Seasonal } \\
\text { wetlands } \\
r^{2}\end{array}$ & $\begin{array}{c}\text { Semipermanent } \\
\text { wetlands } \\
r^{2}\end{array}$ & & \\
\hline Blue-winged Teal & 0.47 & 0.42 & 0.34 & 0.31 & 0.44 \\
\hline Mallard & 0.09 & 0.23 & 0.32 & 0.30 & 0.27 \\
\hline Northern Pintail & 0.19 & 0.30 & 0.38 & 0.12 & 0.35 \\
\hline Northern Shoveler & 0.34 & 0.48 & 0.43 & 0.34 & 0.49 \\
\hline
\end{tabular}




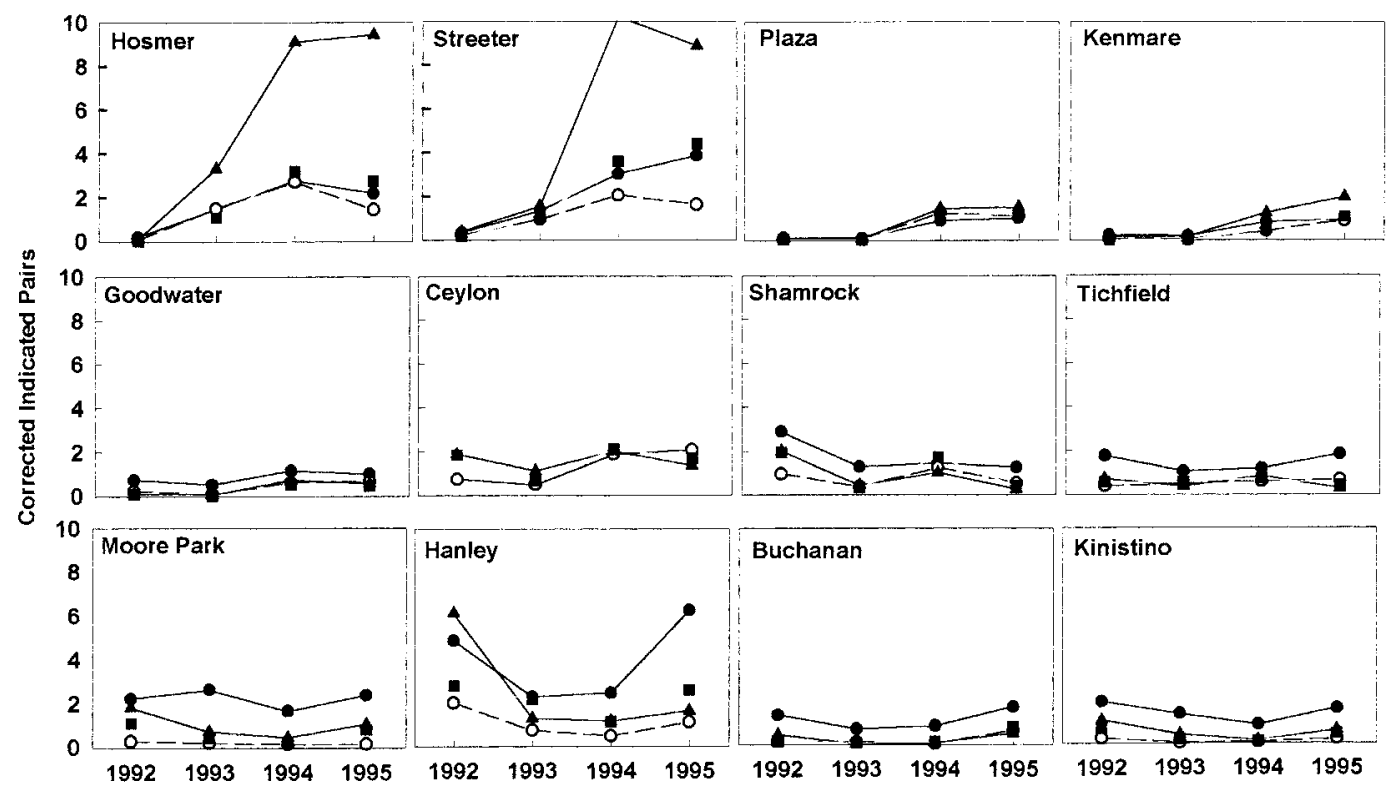

Figure 4. Population indices (corrected indicated pairs) for Mallard (filled circles), Northern Pintail (open circle), Blue-winged Teal (triangle), and Northern Shoveler (square) in twelve study areas in the Dakotas, Manitoba, and Saskatchewan during May, 1992-1995.

basin are impacted by cultivation or grazing [Turner et al. 1987]; sedimentation of basins [Gleason and Euliss 1998], food base, and possibly some measure of the geographic location within the flyway for that species.

Results of this study are constrained by a relatively short time frame (4 years). Although the twelve areas selected for this study included a wide range of landscape features, only a portion of the areas experienced the full range (dry to wet) of water conditions during the four years. Also, some areas may not have as dramatic a response in numbers for some duck species because they are not in the heart of the breeding range or habitat for that species (e.g., Northern Pintail in northeastern parkland areas). Water levels in some study areas were unusually variable during the four years of the study, consequently this short-term study is likely to underestimate long-term temporal variation or overestimate the explanatory value of mean water levels. A broader study that included study areas from South Dakota through Alberta and that extend over a longer time period would be appropriate to capture natural variation and response of ducks to varying area and year conditions.
For all species, substantial variation remained after variation due to area and year were considered. Inclusion of some measure of water condition reduced residual variance by one-third to one half for Blue-winged Teal and Northern Shoveler. But only inclusion of semipermanent water levels removed much of the variation for Mallard and Northern Pintail. For all species, however, a considerable amount of variance still remained unexplained after inclusion of area, year, and water conditions. At least some of the unexplained variation likely is due to the ability to precisely measure duck numbers and water conditions. Additional factors to consider are influence of settling patterns in southern areas (reducing numbers available to settle in northern areas) and continental population size. Johnson (1996) found a significant positive correlation between the size of the continental population of Northern Pintail and their numbers at the Woodworth Study Area in central North Dakota over a 25-year period. During this study, the continental population of Northern Pintail was near a record low (U.S. Fish and Wildlife Service and Canadian Wildlife Service 1996), which may have limited numbers available to fill existing habitat. 
Variation in duck counts that could be explained strictly by variation in water levels or pond densities in this study was modest or poor relative to variation explained in studies that have measured water conditions and duck numbers across larger geographic scales, such as WBPHS strata (Johnson and Grier 1988; Batt et al. 1989). This result is a natural consequence of working at a relatively fine scale of spatial resolution for at least two reasons. First, the relation between duck numbers and water conditions is indeed likely to be stronger at coarser spatial scales than at the scale studied here because waterfowl are not evenly distributed within areas of similar water condition. Factors such as food availability (Murkin et al. 1982) and vegetative cover (Weller and Fredrickson 1974) can affect duck use of individual wetlands. Such local variations in duck numbers are smoothed to a progressively greater degree as the size of the study area increases, strengthening relations between duck numbers and water conditions. Second, sampling error, a component of unexplained variation, tends to decrease as the number of ducks counted and the size of the wetland sample increases, and thus tends to be less for large areas than for small ones. Unless sampling error is a negligible component of unexplained variation, direct comparisons of correlation coefficients and coefficients of determination are inappropriate. Smaller coefficients should be expected for smaller study areas than for larger ones when duck counts or measurements of water conditions are imprecise, which is often the case.

When annual variation in duck numbers is examined at the large regional scales of WBPHS strata $\left(7,300-65,587 \mathrm{~km}^{2}\right.$; Smith 1995), May pond numbers seem to be the dominant factor affecting Mallard numbers and distribution (Johnson and Grier 1988; Batt et al. 1989). However, numbers of Mallard on small $\left(<13 \mathrm{~km}^{2}\right)$ individual study areas in Saskatchewan (Leitch and Kaminski 1985) and central North Dakota (Johnson 1996) were not significantly correlated with May pond numbers. My study was conducted at an intermediate scale (multiple study areas of $280 \mathrm{~km}^{2}$ each). While pond densities in concert with area and year provided a reasonably good model to predict Mallard numbers, consideration of pond densities alone left a large proportion of variation unexplained. These results again point to the importance of recognizing other area-related factors.

Consideration of results from this and other studies indicate that efforts to relate the distribution of waterfowl relative to water conditions may produce differing results depending on spatial scale, and that other factors must also be considered. While philopatry (Lokemoen et al. 1990; Arnold and Clark 1996) and wetland quality likely influence duck numbers at a local scale, other factors such as upland habitat conditions (Krapu et al. 1997; Austin et al. 2001), pond densities, wetland classes (Stewart and Kantrud 1973), or total water availability (Cowardin et al. 1998) may operate at a variety of scales. Dzubin (1969b) cautioned that relations between pond numbers and number of breeding pairs should be examined for each species separately and be tempered with additional data on quality, size, distribution, and density of ponds, and availability of upland cover. Pond densities, while readily obtained and often the only measure of habitat quality in long-term data sets, do not provide a complete picture of habitat conditions that attract breeding ducks. Some measure of the amount of water contained in wetlands, such as water levels or total water area, may provide a useful alternative or additional measure of wetland quality within and among years. The proportional distribution of wetland classes should also be considered in light of species preferences. More complex analyses of various landscape factors, at various scales, are needed to better understand the relationship between duck numbers and wetlands.

\section{ACKNOWLEDGMENTS}

I thank J. A. Anderson, S. W. Chattin, J. C. Ferdinandsen, G. D. Gylten, G. B. Harper, D. K. Kottenbrock, D. R. Lance, G. G. Mack, M. V. Slivinski, R. H. Terry, and B. T. Vogl for data collection. G. A. Sargeant provided valuable statistical analyses and insight regarding issues of scale. W. E. Newton also provided assistance with statistical analyses and review. I appreciate the comments on earlier drafts made by A. D. Afton, R. G. Clark, D. C. Duncan, G. A. Sargeant, and M. H. Sherfy. Funding was 
provided by U.S. Fish and Wildlife Service and National Biological Service through Northern Prairie Wildlife Research Center.

\section{LITERATURE CITED}

Arnold, T. W. and R. G. Clark. 1996. Survival and philopatry of female dabbling ducks in south-central Saskatchewan. Journal of Wildlife Management 60: 560-568.

Austin, J. E., T. Buhl, G. R. Guntenspergen and H. T. Sklebar. 2001. Duck populations as indicators of landscape condition in the prairie pothole region. Environmental Monitoring and Assessment 69: 29-47.

Austin, J. E. and M. R. Miller. 1995. Northern Pintail (Anas acuta). In The Birds of North America, No. 163 (A. Poole and F. Gill, Eds.). The Academy of Natural Sciences, Philadelphia, and American Ornithologists' Union, Washington, D.C.

Batt, B. D. J., M. G. Anderson, C. D. Anderson and F. D. Caswell. 1989. The use of prairie potholes by North American ducks. Pages 204-227 in Northern prairie wetlands (A. Van der Valk, Ed.). Iowa State University Press, Ames.

Bellrose, F. C. 1980. Ducks, geese, and swans of North America. Stackpole Books, Harrisburg, Pennsylvania.

Burnham, K. P. and D. R. Anderson. 1998. Model selection and inference: a practical information-theoretic approach. Springer-Verlag, New York.

Cowardin, L. M., P. J. Pietz, J. T. Lokemoen, H. T. Sklebar and G. A. Sargeant. 1998. Response of nesting ducks to predator exclosures and water conditions during drought. Journal of Wildlife Management 62: 152-163.

Cowardin, L. M., T. L. Shaffer and P. M. Arnold. 1995. Evaluations of duck habitat and estimation of duck population sizes with a remote-sensing-based system. U. S. Department of Interior, National Biological Service Biological Report 2.

Crissey, W. F. 1969. Prairie potholes from a continental viewpoint. Pages 161-171 in Saskatoon Wetlands Seminar. Canadian Wildlife Service Report Series 6.

Drewien, R. C. and P. F. Springer. 1969. Ecological relationships of breeding Blue-winged Teal to prairie potholes. Pages 102-115 in Saskatoon Wetland Seminar. Canadian Wildlife Service Report Series 6.

Dzubin, A. 1969a. Assessing populations of ducks by ground counts. Pages 178-230 in Saskatoon Wetland Seminar. Canadian Wildlife Service Report Series 6.

Dzubin, A. 1969b. Comments on carrying capacity of small ponds for ducks and possible effects of density on Mallard production. Pages 138-160 in Saskatoon Wetland Seminar. Canadian Wildlife Service Report Series 6.

Evans, C. D. and K. E. Black. 1956. Duck production studies on the prairie potholes of South Dakota. U.S. Fish and Wildlife Service Special Scientific Report Wildlife 32.

Gleason, R. A. and N. H. Euliss, Jr. 1998. Sedimentation of prairie wetlands. Great Plains Research 8:97-112.
Greenwood, R. J., A. B. Sargeant, D. H. Johnson, L. M. Cowardin and T. L. Shaffer. 1995. Factors associated with duck nest success in the Prairie Pothole Region of Canada. Wildlife Monograph 128.

Johnson, D. H. 1996. Waterfowl communities in the northern Great Plains. Pages 391-418 in Long-term studies of vertebrate communities (M. L. Cody and J. A. Smallwood, Eds.). Academic Press, San Diego, CA.

Johnson, D. H., and J. W. Grier. 1988. Determinants of breeding distributions of ducks. Wildlife Monograph 100. 37 pp.

Kantrud, H. A., G. L. Krapu and G. A. Swanson. 1989. Prairie basin wetlands of the Dakotas: a community profile. U.S. Fish and Wildlife Service Biological Report $85(7.28)$.

Kiel, W. H., Jr., A. S. Hawkins and N. G. Perret. 1972. Waterfowl habitat trends in the aspen parkland of Manitoba. Canadian Wildlife Service Report Series 18.

Krapu, G. L., R. J. Greenwood, C. P. Dwyer, K. M. Kraft and L. M. Cowardin. 1997. Wetland use, settling patterns, and recruitment in Mallards. Journal of Wildlife Management 61:736-746.

Leitch, W. G. and R. M. Kaminski. 1985. Long-term wetland-waterfowl trends in Saskatchewan grasslands. Journal of Wildlife Management 49: 212-222.

Littell, R. C., G. A. Milliken, W. W. Stroup and R. W. Wolfinger. 1996. SAS system for mixed models. SAS Institute, Inc. Cary, NC.

Lokemoen, J. T., H. F. Duebbert and D. E. Sharp. 1990. Homing and reproductive habits of Mallards, Gadwalls, and Blue-winged Teal. Wildlife Monograph 106. $28 \mathrm{pp}$.

Murkin, H. R., R. M. Kaminski and R. D. Titman. 1982. Responses by dabbling ducks and aquatic invertebrates to an experimentally manipulated cattail marsh. Canadian Journal of Zoology 60:2324-2332.

Smith, G. W. 1995. A critical review of the aerial and ground surveys of breeding waterfowl in North America. U.S. Department of Interior, National Biological Service Biological Science Report 5.

Stewart, R. E. and H. A. Kantrud. 1971. Classification of natural ponds and lakes in the glaciated prairie region. U.S. Fish Wildlife Service Resource Publication $92.56 \mathrm{pp}$.

Stewart, R. E. and H. A. Kantrud. 1973. Ecological distribution of breeding waterfowl populations in North Dakota. Journal of Wildlife Management 37: 39-50.

Turner, B. C., G. S. Hochbaum, F. D. Caswell and D. J. Nieman. 1987. Agricultural impacts on wetland habitats on the Canadian prairies, 1981-85. Transaction of North American Wildlife Natural Resource Conference 52: 206-215.

U.S. Fish and Wildlife Service and Canadian Wildlife Service. 1987. Standard operating procedures for aerial waterfowl breeding ground population and habitat surveys in North America. Office of Migratory Bird Management, Laurel, Maryland. $108 \mathrm{pp}$.

Weller, M. W. and L. H. Fredrickson. 1974. Avian ecology of a managed glacial marsh. Living Bird 12: 269-291. 